\title{
The Econometric Theory Awards 2011
}

I am delighted to announce the following Econometric Theory Awards for 2011.

$\begin{array}{ll}\text { Multa Scripsit (2011): } & \text { Juan Carlos Escanciano } \\ & \text { Patrik Guggenberger } \\ & \text { Yongmiao Hong } \\ & \text { George Kapetanios } \\ & \text { Xiaofeng Shao } \\ & \text { Wei Biao Wu } \\ & \text { Eric Zivot }\end{array}$

Plura Scripsit (2011): $\quad$ Herman J. Bierens

Plurima Scripsit (2011): $\quad$ Donald W. K. Andrews

Lung fei-Lee

Oliver Linton

There are presently three levels of ET award: Multa Scripsit, Plura Scripsit, and Plurima Scripsit. The awards are made annually using an automated point system based on an author's cumulative publications in ET. A description of the award system and a copy of the ET Award Certificate are given in the Vol. 13, No. 2 issue of ET and may be viewed on the $E T$ website at http://korora.econ.yale.edu/et/.

Cambridge University Press joins me in congratulating the recipients of the 2011 ET Awards and thanking them for their sustained contributions to econometric theory.

Peter C. B. Phillips January 2011 